\title{
Persepsi Perawat tentang Customer Service yang Diaplikasikan oleh Perawat di Rumah Sakit Swasta
}

\author{
Setiawan, Dewi Elizadiani Suza, Cholina Trisa Siregar \\ Fakultas Keperawatan, Universitas Sumatera Utara \\ Email: setia-06@hotmail.com
}

\begin{abstract}
Abstrak
Customer service merupakan upaya yang dapat dilakukan suatu organisasi untuk memberikan kepuasan bagi konsumen. Istilah customer service lebih dikenal di dunia bisnis, namun aplikasi customer service juga dapat ditemukan di dunia kesehatan. Penerapan customer service di rumah sakit dapat meningkatkan kinerja pegawai rumah sakit termasuk perawat. Penelitian ini bertujuan untuk menggali persepsi perawat tentang aplikasi customer service oleh perawat di sebuah rumah sakit swasta di Indonesia. Penelitian ini merupakan satu siklus studi action research yaitu tahap reconnaissance yang dilakukan di rumah sakit swasta di Medan. Tahap reconnaissance merupakan satu fase yang penting dalam pendekatan action research yang bertujuan untuk menemukan thematic concern dari setting penelitian. Jumlah partisipan dalam penelitian ini adalah sebanyak 10 perawat pelaksana. Partisipan direkrut dalam penelitian ini dengan menggunakan teknik purposive sampling. Data kualitatif dikumpulkan melalui teknik focus group discussion (FGD). Data yang diperoleh dianalisis dengan menggunakan pendekatan content analysis. Hasil penelitian ini mengungkapkan 4 tema persepsi perawat tentang costumer service, yaitu: 1) makna costumer service menurut perawat pelaksana (memberikan pelayanan maksimal, pemenuhan kebutuhan pasien, dan interaksi dan komunikasi efektif,); 2) Upaya perawat dalam mengaplikasikan customer service (sikap professional perawat, ketulusan, mengatasi masalah pasien, dan menciptakan caring moment); 3) Hambatan dalam menerapkan customer service dalam pelayanan keperawatan (kurangnya pemahaman pasien terhadap penjelasan yang diberikan, permintaan pasien yang berlebihan selama perawatan, kurangnya reward terhadap pekerjaan yang telah dilakukan); 4) Upaya meningkatkan aplikasi customer service dalam pelayanan keperawatan (sabar dan tulus dalam menghadapi keluarga pasien, tanggap dalam pemenuhan kebutuhan pasien, peningkatan pendidikan perawat, memberikan reward kepada perawat, dan memfasilitasi hubungan pasien dengan dokter).
\end{abstract}

Kata kunci: Action Research, customer service, Rumah Sakit Swasta.

\section{Nurses' Perceptions about Customer Service as Applied by Nurses in Private Hospital}

\begin{abstract}
Customer service is an effort to improve patients' satisfaction. The term customer service is known in the business world; however, application of customer service also can be found in the health setting. The application of customer service in hospitals can increase the performance of hospital staffs including nurses. This study aimed to explore the nurses' perception about application of customer service by nurses in a private hospital in Indonesia. This study is a cycle of action research which is reconnaissance stage that was conducted in a hospital in Medan. The reconnaissance is an important factor in action research which aimed to find thematic concern from a research setting. Participants in this study were nurses which recruited using purposive sampling technique. Qualitative data were collected using focus group discussion (FGD). The data were analyzed using content analysis. The results showed that there were 4 themes regarding nurses' perceptions of customer service, namely 1) the meaning of customer service according to the nurses (giving optimal service, fulfillment of clients' needs, and effective interaction and communication; 2) Nurses' efforts to apply customer services (professional attitude, sincere, overcome clients' problem, and creating caring moment); 3) Barriers in applying customer services (lack of patients' understanding about the information given, unrealistic requests from patients, lack of rewards for nurses; 4) Efforts to improve customer service application in nursing services (patients and sincere in giving service, responsive towards patients' needs, improvement of nurses' education, rewards for nurses, facilitating relationships with patients with doctors).
\end{abstract}

Keywords: Customer Service, Action Research, Private Hospitals. 
Setiawan: Persepsi Perawat tentang Customer Service yang Diaplikasikan oleh Perawat

\section{Pendahuluan}

Pertumbuhan rumah sakit swasta di Indonesia dalam dekade terakhir ini cukup tinggi terutama di kota besar. Masing-masing rumah sakit swasta menawarkan berbagai bentuk dan cakupan pelayanan yang beragam untuk menarik minat pasien mencari pelayanan rumah sakit yang terbaik. Rumah sakit swasta harus berfokus pada pembangunan cakupan dan skala pelayanan yang bermakna, integritasi pemberian pelayanan dan manajemen, biaya (cost) yang kompetitif, mendemonstrasikan mutu klinis yang tinggi dan diferensiasi dengan kompetitor melalui customer service yang mumpuni agar rumah sakit swasta bisa kompetitif (McCarthy, 2012). Selain itu, rumah sakit swasta yang lebih berorientasi profit dibanding rumah sakit pemerintah, mengandalkan revenue yang tergantung pada atraksi konsumen dan loyalitasnya sehingga konsumen yang puas dengan pelayanan rumah sakit merupakan aset bagi rumah sakit swasta (Haque, Sarwar, Yasmin, Anwar, \& Nuruzzaman. (2012).

Banyak rumah sakit di luar negeri menerapkan konsep customer service dalam memberikan pelayanan bagi pasien. Menurut Howard (2000) penerapan customer service yang baik di rumah sakit mempunyai beberapa keuntungan antara lain meningkatnya kepuasan pasien, meningkatnya mutu fungsional secara keseluruhan, dan manfaat dari aspek finansial (penghematan biaya pada beberapa area pelayanan rumah sakit). Studi yang dilakukan oleh Ellis-Jacobs (2011) menunjukkan hubungan yang signifikan antara keterampilan customer service praktisi rumah sakit dengan kesuksesan finansial rumah sakit. Ellis-Jacobs menemukan bahwa penerapan customer service oleh pegawai rumah sakit meningkatkan pendapatan rumah sakit sekaligus meningkatnya kepuasan pasien.

Untuk membantu meningkatkan mutu pelayanan rumah sakit, maka kualitas layanan keperawatan harus dapat dilakukan dengan maksimal yang merujuk pada konsistensi dalam menerapkan customer service dalam setiap penyediaan layanan yang sesuai dengan yang dibutuhkan dan diharapkan oleh pasien. Dengan demikian, sukses atau tidaknya kompetisi antara rumah sakit swasta sangat tergantung pada kepuasan konsumen yang ditentukan oleh penilaian kualitas layanan berdasarkan apa yang dirasakan pelanggan (Foster, 2016). Pengaplikasian customer service di rumah sakit swasta saat ini sudah banyak digunakan pada level penerimaan pasien baru oleh petugas customer service khusus. Seharusnya pengalaman customer service harus didapatkan pasien melalui semua staf yang ada di rumah sakit yang melakukan kontak dengan pasien yang merupakan bagian dari sistem operasi rumah sakit (Ullah \& Islam, 2011). Perawat merupakan staf rumah sakit yang jumlahnya paling banyak dan paling sering berinteraksi dengan pasien dan keluarga maka perawat perlu memahami dan mengerti dengan baik makna customer service dan mampu mengaplikasikan kegiatan customer service di rumah sakit. Pihak manajemen rumah sakit dan bidang keperawatan juga harus mampu berkomitmen kuat untuk menginisiasi, memfasilitasi dan mengevaluasi program customer service bagi perawat. Namun, dari studi kepustakaan yang dilakukan, pemahaman perawat rumah sakit swastamengenaicustomer service masih sangat minim. Mempertimbangkan hal tersebut, maka perlu dikaji bagaimana sebenarnya persepsi perawat mengenai customer service dalam pelayanan keperawatan di rumah sakit swasta.

Perawat mempunyai peran penting dalam penerapan customer service di rumah sakit dan fasilitas kesehatan lainnya. Hal ini terkait erat dengan karakteristik kerja perawat yang paling sering dan paling lama dalam berinteraksi langsung dengan pasien ataupun keluarga pasien sehingga impresi yang baik tentang pelayanan rumah sakit bisa tercermin dari cara perawat dalam melayani pasien. Oleh karena itu, pengetahuan dan keterampilan customer service perlu diberikan bagi perawat dalam upaya untuk mengaplikasikan customer service dalam pelayanan keperawatan. Sebuah studi yang dilakukan oleh Mayer et al (1998) tentang pelatihan customer service yang berfokus pada aspek klinis di ruang emergensi menunjukkan bahwa terjadi peningkatan keterampilan perawat dalam penerapan customer service dan juga terjadi peningkatan kepuasan pasien. Oleh karena itu, penelitian ini bertujuan untuk menggali persepsi perawat tentang aplikasi customer service oleh perawat di sebuah rumah sakit swasta di Indonesia. 
Setiawan: Persepsi Perawat tentang Customer Service yang Diaplikasikan oleh Perawat

\section{Metode Penelitian}

Penelitian ini merupakan satu siklus studi action research yaitu tahap reconnaissance yang dilakukan di rumah sakit swasta di Medan. Tahap reconnaissance merupakan satu fase yang penting dalam pendekatan action research yang bertujuan untuk menemukan thematic concern dari setting penelitian (Kemmis, McTaggart, \& Nixon, 2014). Thematic concern ini diperoleh dengan melakukan pengumpulan data yang salah satunya adalah data kualitatif. Setelah ditetapkan thematic concern di setting penelitian maka proses penelitian dilanjutkan ke siklus action research yaitu planning, acting, observing, dan reflecting. Partisipan dalam penelitian ini adalah sebanyak 10 perawat pelaksana yang telah bekerja lebih dari satu tahun dengan pengambilan sampel menggunakan teknik purposive sampling.

Data dikumpulkan melalui Focus Group Discussion (FGD) yang diawali dengan memberikan pertanyaan terbuka dan didiskusikan bersama dengan waktu lebih kurang 60 menit. Dalam melakukan FGD, peneliti menggunakan panduan FGD sebagai alat bantu dalam mengajukan pertanyaan kepada para partisipan. Data yang diperoleh dari FGD dibuat dalam bentuk transkrip. Transkrip dari FGD ini kemudian dianalisis menggunakan teknik content analysis.

\section{Hasil Penelitian}

Partisipan penelitian adalah 10 orang perawat pelaksana yang seluruhnya adalah perempuan dengan umur rata-rata di atas 25 tahun. Enam orang perawat pelaksana memiliki masa kerja antara 1-10 tahun dan 6 orang perawat pelaksana memiliki masa kerja 11-21 tahun.

Penelitian ini mengungkapkan empat tema yaitu: (1) Makna costumer service menurut perawat pelaksana, (2) Upaya perawat dalam mengaplikasikan customer service, (3) Hambatan dalam menerapkan customer service dalam pelayanan keperawatan, (4) Upaya untuk meningkatkan aplikasi customer service dalam pelayanan keperawatan.

\section{Makna customer service menurut perawat pelaksana}

Perawat dalam penelitian ini mempersepsikan 3 makna customer service yang diaplikasikan oleh perawat di rumah sakit. Ketiga makna tersebut yaitu memberikan pelayanan maksimal, pemenuhan kebutuhan pasien, dan interaksi dan komunikasi efektif.

\section{a) Memberikan pelayanan maksimal}

Perawat menyatakan bahwa salah satu makna dari customer service adalah memberikan pelayanan yang maksimal kepada pasien. Pelayanan yang maksimal ini bertujuan untuk meningkatkan kepuasan bagi pasien sebagai penerima pelayanan keperawatan. Hal ini sesuai dengan pernyataan partisipan sebagai berikut:

"customer service itu adalah tindakan pelayanan yang diberikan...untuk mencapai kepuasan antara pemberi pelayanan dan yang diberi pelayanan" [Partisipan 4]

\section{b) Pemenuhan kebutuhan pasien}

Perawat dalam memberikan pelayanan harus mampu memenuhi kebutuhan pasien sesuai dengan keinginannya berdasarkan standar yang ditetapkan. Dalam memenuhi kebutuhan pasien ini, perawat perlu bersikap proaktif dengan bertanya tentang apa yang dibutuhkan pasien dan menyatakan kesiapan perawat untuk selalu membantu pasien bilamana pasien membutuhkan pelayanan dari perawat. Hal ini sejalan dengan pernyataan partisipan berikut ini:

"sebelum kita melakukan tindakan pada pasien, kita datang ke rumah sakit, kita baca rawatan dulu setelah kita membaca rawatan baru kita operan keruangan kita melihat keadaan pasien kita yang kita tangani setelah itu baru kita adakan komunikasi satu persatu kepada pasien kita yang kita tangani, karena di rumah sakit ini ada sistim pembagian pasien dalam satu ruangan itu ada beberapa pasien yang harus kita kuasai, jadi sebelum mereka mengeluh dengan keluhan mereka terlebih dahulu kita selalu bertanya kalau ada yang kurang, kalau ada yang tidak enak boleh ibu pencet bel, boleh panggil kami dan nanti kalaupun tidak saya yang datang atau 
Setiawan: Persepsi Perawat tentang Customer Service yang Diaplikasikan oleh Perawat

teman saya yang datang itu sama saja bu, ibu keluhkan saja bu apa keluhan ibu" [Partisipan $3]$.

\section{c) Interaksi dan komunikasi yang efektif}

Melakukan interaksi dan berkomunikasi yang efektif merupakan makna cuctomer service yang disampaikan oleh partisipan dalam penelitian ini. Hal ini dilakukan perawat untuk membentuk hubungan saling percaya antara perawat dan pasien. Dalam berinteraksi perawat berupaya untuk melakukan kontak mata, berbicara dengan lembut dan juga bertanya tentang apa yang dialami pasien dengan menjalankan teknik komunikasi yang efektif. Makna customer service ini sesuai dengan pernyataan 2 orang partisipan berikut ini:

"customer service itu makna adalah melakukan interaksi dengan pasien seperti dengan menanyakan apa keluhannya, dimana sakitnya, kenapa masuk rumah sakit, ya kita tanyakan sama keluarga dan tanyakan sama pasiennya" [Partisipan 1]

"...melakukan kontak mata, tersenyum, berkomunikasi dengan berbicara lemah lembut seperti itulah yang kami lakukan sehari-hari" [Partisipan 10]

\section{Upaya perawat dalam mengaplikasikan customer service}

Partisipan dalam penelitian ini menyatakan bahwa ada beberapa upaya perawat dalam mengaplikasikan customer service dalam praktek keperawatan di rumah sakit yaitu sikap professional perawat, ketulusan, mengatasi masalah pasien, dan menciptakan caring moment.

\section{a) Sikap professional perawat}

Perawat dalam memberikan pelayanan keperawatan harus bersikap professional dengan memenuhi kebutuhan pasien sesuai dengan standar prosedur dan aturan rumah sakit serta membantu pasien dalam mengambil keputusan tentang perawatan kesehatannya. Pernyataan ini sesuai dengan pernyataan partisipan di bawah ini:

"Upaya kami adalah tetap bersikap profesional misalnya dengan mengarahkan pasien yang ingin pindah ke RS lain dengan BPJS ... silahkan ibu... kita akan arahkan sampai kita akan mendapatkan rumah sakit yang kerjasama dengan BPJS dan ICU-nya ada" [Partisipan 3]

\section{b) Ketulusan}

Ketulusan merupakan salah satu upaya yang dilakukan oleh partisipan dalam penelitian ini untuk mengaplikasikan custome service di rumah sakit. Perawat memberikan pelayanan keperawatan tidak untuk mengharapkan imbalan dari pasien, namun secara sadar berupaya untuk membantu pasien dalam meningkatkan derajat kesehatannya. Dengan ketulusan dalam melayani pasien, partisipan berharap dapat memberikan pelayanan yang terbaik bagi pasien. Upaya ini sejalan dengan pernyataan partisipan berikut ini:

"kalo menurut saya upaya yang saya telah saya lakukan adalah dengan melayani pasien secara tulus...jadi seorang perawat harus tulus dalam memberikan asuhan keperawatan bagi pasien" [Partisipan 5].

\section{c) Mengatasi masalah pasien}

Upaya lain yang dilakukan partisipan dalam mengaplikasikan customer service di rumah sakit adalah dengan berupaya maksimal untuk mengatasi masalah pasien. Mengatasi masalah pasien dilaksanakan dengan secara aktif menggali keluhan pasien ataupun menerima keluhan pasien dengan terbuka. Bila ada pasien yang menyampaikan keluhan partisipan menyampaikan pernyataan maaf dan selanjutnya partisipan berupaya untuk mencari jalan keluar untuk segera mengatasi keluhan tersebut. Hal ini sesuai dengan pernyataan partisipan di bawah ini:

"penyelesaian komplain, perawat yang dikomplain dipanggil ke ruangan oleh kepala perawat ruangan sebelum ke kepala ruangan menanyakan apa yang dikeluhkan keluarga kepada perawat yang dikomplen dan bila perlu keluarga yang mengkomplen diikutsertakan di ruangan kepala ruangan itu dan ditanyakan kepada keluarga yang komplen, komplain yang dikomplenkannya keluarga itu apa, mengenai satu suster yang ini, jadi, bila keluarga itu 
Setiawan: Persepsi Perawat tentang Customer Service yang Diaplikasikan oleh Perawat

sudah selesai bicara baru perawat boleh menjawab dengan minta maaf bilapun saya salah saya tolong dimaafkan baru kepala ruangan meluruskan permasalahan tersebut" [Partisipan 4].

\section{d) Menciptakan caring moment}

Untuk menerapkan customer service dalam praktik keperawatan sehari-hari, upaya yang telah dilakukan partisipan dalam penelitian ini adalah dengan menciptakan caring moment. Partisipan berupaya untuk memberikan impresi yang baik bagi pasien selama berinteraksi dengan mereka dan keluarganya. Interaksi selalu dilakukan dengan mengucapkan salam dan menyebutkan nama pasien.

"kami berupaya untuk menciptakan caring moment dengan cara misalnya shift pagi saya ni ya, kita masuk ke ruangan pasien dan kita sebagai perawat harus sudah tau nama pasien, kita berikan salam selamat pagi ibu $K$ saya suster $M$... bagaimana tadi malam apakah ibu bisa tidur dengan nyenyak, lalu kita tanyakan keluhannya..kalo ada keluhan kita kasih tau pasiennya agar cepat memberitahu ke suster dan keluarganya juga kita beritahu tentang itu” [Partisipan 8]

\section{Hambatan dalam menerapkan aplikasi customer service dalam pelayanan keperawatan}

Dalam upaya menerapkan customer service di rumah sakit, partisipan merasakan adanya beberapa hambatan. Hambatan ini antara lain kurangnya pemahaman pasien terhadap penjelasan yang telah diberikan, permintaan pasien yang terlalu berlebihan selama perawatan, dan kurangnya reward terhadap pekerja yang telah dilakukan.

\section{a) Kurangnya pemahaman pasien terhadap} penjelasan yang telah diberikan

Kurang pahamnya pasien terhadap penjelasan yang diberikan perawat kepada pasien dapat dilihat dari sulitnya pasien mengerti tentang penjelasan mengenai pengobatan maupun perawatan yang diberikan perawat. Hal ini sesuai dengan pernyataan pasien berikut ini:

"komunikasi saja sulit...padahal kita sudah memberikan penjelasan tujuan dari pengobatannya...tetapi dia tidak memahami bahasa kita itu" [Partisipan 4 ]

\section{b) Permintaan pasien yang terlalu berlebihan selama perawatan}

Salah satu hambatan yang dialami oleh partisipan dalam mengaplikasikan customer service di rumah sakit adalah terkadang ada permintaan pasien yang terlalu berlebihan selama mendapatkan pelayanan keperawatan. Permintaan yang berlebihan ini dapat memengaruhi psikologis partisipan walaupun partisipan tetap berupaya memberikan pelayanan yang baik. Terkadang partisipan merasa terpaksa harus memenuhi permintaan pasien tersebut padahal permintaan tersebut bisa dilakukan pasien secara mandiri.

"Hambatannya misalnya terkadang ada permintaan pasien yang berlebihan. Sebagai contoh ada pasien yang cuma minta tolong ambilkan pipet...padahal pasien tersebut mampu melakukannya sendiri.....kayak gitu sih yang membuat kita kadang jengkel ..tapi... yaa gimana...ya memang harus...harus kita lakukan" [Partisipan 3].

\section{c) Kurangnya reward terhadap pekerjaan yang telah dilakukan}

Hambatan lain yang dirasakan partisipan dalam mengaplikasikan customer service di rumah sakit adalah kurangnya reward terhadap pekerjaan yang telah mereka lakukan. Partisipan merasa perlu diberikan reward yang lebih dari yang telah didapat saat ini. Reward ini antara lain dalam bentuk pendidikan lanjut dan juga keikutsertaan dalam diklat baik yang dilakukan di dalam ataupun di luar rumah sakit.

"selain membutuhkan pendidikan dan diklat tadi ya...karena saya rasakan pekerjaan perawat sangat berat dan butuh konsentrasi tapi rewardnya masih dirasakan kurang" [Partisipan 10].

\section{Upaya untuk meningkatkan aplikasi customer service dalam pelayanan keperawatan}

Partisipan dalam penelitian menyampaikan 
Setiawan: Persepsi Perawat tentang Customer Service yang Diaplikasikan oleh Perawat

beberapa upaya yang dapat dilakukan untuk lebih meningkatan aplikasi customer service dalam pelayanan keperawatan di rumah sakit. Upaya ini antara lain sabar dan tulus dalam menghadapi keluarga pasien, tanggap dalam pemenuhan kebutuhan pasien, peningkatan pendidikan perawat, memberikan reward kepada perawat, dan memfasilitasi hubungan pasien dengan dokter.

\section{a) Sabar dan tulus dalam menghadapi keluarga pasien}

Tetap bersikap sabar dan tulus dalam menghadapi keluarga pasien merupakan salah satu upaya perawat dalam menerapkan customer service di rumah sakit. Perawat harus tetap sabar walaupun terkadang mendapati perlakuan yang kurang baik dari keluarga pasien. Perawat juga harus tulus dalam menghadapi ketidaksabaran keluarga pasien. Hal ini sesuai dengan pernyataan partisipan berikut ini:

"Kami harus tetap melayani pasien dan keluarganya dengan baik walaupun terkadang ada mendapat bentakan dari keluarga pasien....terus terang saya menangis dibentak oleh keluarga pasien...yaa mau gimana lagi kan kita harus sabar, ikhlas dan tulus, tak ada embel-embel dan ya udah.... ngga berapa lama dia curhat sama pengawas perawatan"(Partisipan 6)

\section{b) Tanggap dalam pemenuhan kebutuhan pasien}

Perawat harus tanggap dalam memenuhi kebutuhan pasien yang dirawat, dan perawat meninggalkan pekerjaan lain ketika bel berbunyi dan perawat langsung menuju kamar pasien. Ini sesuai dengan pernyataan partisipan di bawah ini:

"ada bunyi bel...dan kita buru-buru kesana....dan kita meninggalkan pekerjaan yang kita lakukan....dan kita kesana merespon panggilan pasien. Begitulah upaya yang kami sebagai perawat agar bisa melayani pasien sebaik mungkin" (Partisipan 5)

\section{c) Peningkatan pendidikan perawat}

Partisipanjugamenyatakan bahwa peningkatan pendidkan perawat dapat memperbaiki cara mereka dalam melayani pasien. Perawat harus meningkatkan kualitas pendidikan terutama kemampuan bahasa asing dalam berinteraksi dengan pasien melalui diklat dan pelatihan terutama pendidikan bahasa Inggris. Hal ini didukung oleh pernyataan partisipan berikut ini:

"Meningkatkan pendidikan perawatnya, misalnya dalam pendidikan bahasa Inggris... meningkatkan karir... meningkatkan kualitas dengan memberikan diklat.... pelatihanpelatihan. Memang kalau untuk bahasa kita kurang. Kalau pendidikan kami meningkat tentunya upaya dalam melayani pasien juga akan jauh lebih baik." (Partisipan 7)

\section{c) Memberikan reward kepada perawat}

Pemberian reward kepada perawat merupakan salah satu upaya untuk meningkatkan aplikasi customer service oleh perawat di rumah sakit. Partisipan menyatakan bahwa perawat merupakan pekerjaan serius dan membutuhkan refreshing yang dapat memacu perawat untuk aktif dan loyal dalam memberikan pelayanan. Hal ini sesuai dengan pernyataan partisipan berikut ini:

"...perawat itu kan kerjaannya serius $y a$, dengan mengikuti pelatihan pelatihan dan pelatihan....terkadang dengan biaya sendiri, tapi kalo menurut pikiran normal kita harus ada reward karena reward ini memacu adrenalin perawat untuk lebih aktif lagi melayani dan loyal terhadap rumah sakit ini,'[Partisipan 10]

\section{d) Memfasilitasi hubungan pasien dengan dokter}

Upaya lain yang bisa dilakukan untuk meningkatkan aplikasi customer service oleh perawat di rumah sakit adalah dengan cara perawat memfasilitasi keluarga dan pasien untuk mendapatkan penjelasan dari dokter mengenai kondisi pasien. Perawat harus bisa proaktif agar hubungan atau kontak antara pasien dan keluarga dengan dokter dapat berjalan lebih baik. Hal ini sesuai dengan pernyataan partisipan di bawah ini:

"Kadang kita melakukan kontak supaya meyakinkan pasien itu kita telpon dokternya 
Setiawan: Persepsi Perawat tentang Customer Service yang Diaplikasikan oleh Perawat

bicara dengan dokternya...trus bilang ada keluarga pasien yang ingin berbicara dengan dokter,"[Partisipan 4]

\section{Pembahasan}

Penelitian ini menunjukkan persepsi perawat pelaksana tentang costumer service di sebuah rumah sakit swasta di Kota Medan bahwa dalam mengaplikasikan costumer service, perawat pelaksana harus memberikan pelayanan yang maksimal, memenuhi kebutuhan pasien dengan cara berinteraksi dan komunikasi yang efektif, dan menciptakan suasana caring moment sesuai dengan pengetahuan keperawatan.

Sikap professional perawat merupakan aspek penting yang dibutuhkan dalam mengaplikasikan costumer service dimana perawat pelaksana diharapkan memiliki ketulusan dan kemampuan dalam membantu dan menyelesaikan masalah dengan memberikan solusi bagi pasien untuk memilih tindakan yang terbaik terkait dengan pelayanan kesehatan yang diberikan oleh perawat pelaksana.

Watson (2008) menyatakan bahwa elemen dasar dari pelayanan keperawatan yang berkualitas tinggi adalah pengembangan kualitas hubungan yang saling percaya dan saling membantu antara perawat dan pasien sehingga proses pelayanan keperawatan berjalan dengan baik. Hal ini bisa terwujud apabila perawat di rumah sakit mampu menunjukkan sikap professional mereka dalam melayani pasien. Dengan menunjukkan sikap professional ini perawat bisa meningkatkan upaya rumah sakit dalam menerapkan customer service yang bertujuan memberikan pelayanan yang bermutu. Hal ini sejalan dengan pendapat Ullah dan Islam (2011) yang menyatakan berhasil atau tidaknya penerapan customer service kepada pasien tergantung pada semua personel rumah sakit yang melakukan kontak dengan pasien yang merupakan bagian dari sistem operasi pelayanan rumah sakit terutama hubungan antara perawat dan pasien.

Perawat sering mengalami hambatan dalam mengaplikasikan customer service dalam pelayanan keperawatan. Hambatan ini dirasakan karena tuntutan pasien yang terlalu berlebihan selama menjalani perawatan dan kurangnya pemahaman pasien terlihat dari penjelasan yang diberikan kepada pasien masih belum bisa dipahami oleh pasien terutama penjelasan mengenai pengobatan. Namun persepsi partisipan ini tidak sepenuhnya merupakan hambatan dalam mengaplikasikan customer service di rumah sakit. Dengan adanya tuntutan dari pasien dan kurangnya pemahaman pasien seharusnya menjadi tantangan bagi perawat untuk lebih baik lagi memberikan respons yang positif terhadap keluhan pasien tersebut. Karena kesalahan yang paling sering dilakukan perawat di rumah sakit dalam menerapkan customer service di rumah sakit adalah ketidaktepatan perawat dalam memberikan respon terhadap keluhan yang disampaikan oleh pasien atau keluarga. Dengan demikian, perawat memang diharapkan memberikan respon yang cepat dan tepat dalam menghadapi keluhan yang disampaikan oleh pasien.

Ada beberapa upaya yang dapat dilakukan oleh perawat untuk meningkatkan aplikasi customer service dalam memberikan pelayanan keperawatan. Upaya ini antara lain berusaha meningkatkan pengetahuan dan keterampilan tentang customer service. Ini tentunya membutuhkan pelatihan internal (inhouse training). Selain dengan melaksanakan berbagai pelatihan untuk meningkatkan keterampilan perawat dalam aspek customer service, kegiatan lain yang bisa dilakukan adalah dengan meningkatkan kualitas interaksi antara perawat dan pasien dengan upaya untuk selalu menciptakan caring moment (Watson, 2008). Kualitas interaksi ini tentunya membutuhkan kemauan dari perawat sendiri dalam menciptakan momen-momen yang berkesan bagi perawat di tengah kesibukan mereka dalam menjalankan pekerjaan mereka sehari-hari. Dengan demikian, upaya yang bisa dilakukan untuk meningkatkan aplikasi customer service oleh perawat di rumah sakit dapat dilakukan oleh pihak manajemen dengan membuat pelatihan dan juga oleh perawat sendiri dengan meningkatkan kualitas interaksi dengan pasien.

Perawat harus bersikap profesional dan juga sabar dan tulus dalam menghadapi keluarga pasien serta tanggap dalam 
Setiawan: Persepsi Perawat tentang Customer Service yang Diaplikasikan oleh Perawat

pemenuhan kebutuhan pasien. Hal ini terkait erat dengan bagaimana sikap perawat baik dalam menghadapi pasien yang tentunya sangat kompleks dan unik. Selain itu, agar dapat meningkatkan kepuasan pasien perawat juga harus meningkatkan kemampuan bahasanya agar dapat berinteraksi dengan pasien terutama pendidikan bahasa Inggris. Keterampilan berkomunikasi dan berbahasa asing akan menjadi nilai tambah yang sangat penting bagi perawat untuk dapat berinteraksi lebih baik dengan pasien dan keluarga, Dengan komunikasi yang baik, proses pemberian pelayanan keperawatan kepada pasien akan lebih lancar dan menghilangkan kesalahpahaman dan meminimalisir terjadinya kesalahan (medical error). Sikap professional perawat tentunya memerlukan dedikasi dan kreativitas perawat untuk memperbaiki kinerja mereka terkait dengan aplikasi customer service dalam pelayanan keperawatan di rumah sakit (Budusan, 2017).

\section{Simpulan}

Penelitian ini menemukan empat tema persepsi perawat tentang customer service yang diaplikasikan perawat di rumah sakit swasta yaitu: (1) Makna costumer service menurut perawat pelaksana, (2) Upaya perawat dalam mengaplikasikan customer service, (3) Hambatan dalam menerapkan customer service dalam pelayanan keperawatan, (4) Upaya untuk meningkatkan aplikasi customer service dalam pelayanan keperawatan. Berdasarkan hasil penelitian ini maka direkomendasikan agar rumah sakit swasta perlu menerapkan customer service dalam pelayanan keperawatan. Untuk itu, rumah sakit swasta dapat mempersiapkan perawat dengan memberikan pengetahuan dan keterampilan perawat tentang aplikasi customer service di rumah sakit melalui seminar dan workshop. Penerapan customer service dalam memberikan asuhan layanan keperawatan harus diterapkan perawat dengan meningkatkan pendidikan perawat melalui pelatihan-pelatihan dan monitoring secara berkelanjutan serta dapat mengaplikasikan dalam melaksanakan tugas sehingga kinerja dapat ditingkatkan. Dengan diterapkannya customer service oleh perawat dalam memberikan pelayanan keperawatan di rumah sakit maka diharapkan kepuasan pasien di rumah sakit swasta dapat meningkat.

\section{Daftar Pustaka}

Budusan, D. (2017). Nursing Customer Service Initiative. Available at: http://nursing. advanceweb.com/Features/Articles/NursingCustomer-Service-Initiative.aspx

Foster, S. (2016). Good customer service for patients. British Journal of Nursing, 2016, Vol 25, No 15.

Ellis-Jacobs, K.A. (2011). Quantitative correlational study on impact of patient satisfaction on rural hospital. The Internet Journal of Allied Health Sciences and Practice. 9,4.

Haque, A, Sarwar, A.A, Yasmin, F, Anwar, A \& Nuruzzaman. (2012). The impact of customer perceived service quality on customer satisfaction for private health centre in Malaysia: A structural equation modeling approach. Information Management and Business Review. 4(5).257-267.

Howard, J.E. (2000). Customer service: The key to remaining competitive in managed care. Managed Care Quarterly. 8, 2, 22-28.

Kemmis, S \& McTaggart, R \& Nixon, R. (2014). The action research planner: Doing critical participatory action research. Singapore: Springer.

McCarthy, K.H. (2012). 5 strategies for building a top-performing hospital. Healthcare Financial Management.

Keelson; S, A \& Dodor, A. (2014). Improving the service quality of healthcare in Ghana: The role of locum Nursing. Australian Journal of Bussiness and Management Research.

Mayer, T.A, Cates, R,J., Mastorovich, M,J. \& Royalty, D.L. (1998). Emergency department patient satisfaction: customer service training 
Setiawan: Persepsi Perawat tentang Customer Service yang Diaplikasikan oleh Perawat

improves patient satisfaction and ratings of physician and nurse skill. $J$ Health Manag. $43,5,427-440$.

Tseng, M.M. Qinhai, M. \&bChuan-Jun, S. (1999). Mapping Customers' Service Experience for Operations Improvement. Business Process Management Journal, 5(1), $50-64$.
Ullah, G.M.S \& Islam, M.R. (2011).Factors influencing consumer service experience in private hospitals: a Study from Bangladeshi perspective. Interdisiplinary Journal of Contemporary Research in Business. 3, (5): 138-147.

Watson, J. (2008), Nursing: The Philosophy and Science of Caring. Boston: Little, Brown and Company. 